Georgia State University

ScholarWorks @ Georgia State University

\title{
Of Providence and Rhetoric: The Failure of Alexander Crummell's Anglo-African Nationalism
}

\author{
Elizabeth J. West \\ Georgia State University, ewest@gsu.edu
}

Follow this and additional works at: https://scholarworks.gsu.edu/english_facpub

Part of the English Language and Literature Commons

\section{Recommended Citation}

West, Elizabeth J., "Of Providence and Rhetoric: The Failure of Alexander Crummell's Anglo-African Nationalism" (2004). English Faculty Publications. 20.

https://scholarworks.gsu.edu/english_facpub/20

This Article is brought to you for free and open access by the Department of English at ScholarWorks @ Georgia State University. It has been accepted for inclusion in English Faculty Publications by an authorized administrator of ScholarWorks @ Georgia State University. For more information, please contact scholarworks@gsu.edu. 
Of Providence and Rhetoric: The Failure of Alexander Crummell’s Anglo-African Nationalism

By Elizabeth J. West, Dept. of English, Georgia State University

Background: From America to Liberia

On May 29,1849 black leaders in Philadelphia called a meeting to address their concerns over the rising influence of the Colonization Society. Founded in 1816, the American Colonization Society was organized and supported by prominent whites who, for varying reasons, believed that free blacks should be removed from the United States. Through the efforts of the Colonization Society, Liberia was founded as a colony of the United States. Many white proponents of black expatriation were influenced by the real threat of slave insurrections that were often led and incited by free blacks. Insurrections such as the 1739 Stono Rebellion in South Carolina, the 1800 rebellion led by Gabriel Prosser in Virginia, and most notably the Haitian Revolution in the 1790s reminded white America that its black population represented a real and constant threat to white life as well as white rule. For many whites, this threat to life and authority was accompanied by the additional prospect of black and white sexual unions that could render America a mongrel nation. While there were colonizationists who claimed that they were promoting a plan that best served blacks, few abolitionists subscribed to the scheme.

For the most part, blacks and their white abolitionist sympathizers accused the colonizationists of merely devising a scheme to maintain slavery. The controversy over the Colonization Society, as well as the announcement of Frederick Douglass's attendance, resulted in a significant crowd at the meeting house in 
Philadelphia. Although Liberia had declared its independence in 1847, few black Americans regarded it as a viable opportunity for freed blacks. Overwhelmingly, free blacks in antebellum America saw America as their home and saw themselves as rightful heirs to America's promise of liberty and justice for all. They deemed the Colonization Society a threat to the fulfillment of this promise and its emigration objective as a mere self-serving scheme designed to remove free blacks from America. Those who had come to hear Douglass and to discuss their concerns agreed that the Colonization Society sought to preserve a class system that cast blacks as an underclass slave sector and whites as a free ruling class.

At the close of this meeting, organizers formalized their conclusions and recommendations in a set of resolutions that were published later in the June 15, 1849 issue of The North Star. The fourth resolution consisted of the committee's expression of gratitude to Alexander Crummell, New York native and black Episcopal minister, for his "watchfulness and zeal ... in promptly transmitting to his native land [the U.S.] the warning of [the] enemy's movements." ${ }^{\prime 1}$ The enemy --the American Colonization Society --had dispatched agents to Britain to solicit funds and support in transporting free blacks to Liberia. Crummell had traveled to England in 1847 ostensibly to solicit funds for his black Episcopal mission. While there, he transformed his fundraising campaign into a prolonged stay after he accepted an offer to attend Queen's College. Crummell emerged from his five year stint in England with a degree from Queen's College, but unlike his black activist peers at home, Crummell softened his harsh stance on colonization.

Although Crummell and Douglass were revered and respected in abolitionist and black activist circles, in the 1850s and 1860s they found themselves on different 
sides of the colonization debate. Douglass continued to publish criticisms of colonization, including personal accounts of blacks who had lived in or traveled to Liberia. He was resolute in his argument that America was the home of blacks who were born and had labored on American soil. Douglass further pointed to the colonizationists’ misrepresentation of Liberia as an idyllic refuge for black emigrants. In an 1855 issue of Frederick Douglass' Paper, he recorded the impressions of Mr. William Nesbit who, after spending several months in Liberia, painted a disillusioning picture. Nesbit found Liberia’s climate unbearable for blacks born in the United States. Foremost, however, was his report that over time, black settlers in Liberia demonstrated a "tendency to retrograde and fall back to heathenism," and, paradoxically, that the settlers engaged in an alarming mistreatment of natives. ${ }^{2}$

Crummell, who had a decade earlier been celebrated by his peers in America for his watchful eye of the colonizationists abroad, was by the mid 1850s a crusader for colonization. Numerous extant communications and publications show that Crummell energetically and enthusiastically advocated for the colonization of Liberia. He had begun to speak publicly in support of colonization before he left England. In an 1852 address, “Hope for Africa,” before the Ladies’ Negro Education Society in England, Crummell's advocacy for colonization is evident. Citing Sierra Leone as the example of successful colonization, Crummell weaved a narrative that united concepts of colonization and providence. He explained that the three hundred years of misery and suffering wrought in slavery and the slave trade was "permitted by the Divine will and providence," and that the mystery of God's plan was unfolding as "the recaptured Africans taken to Sierra Leone, civilized and 
Christianized, [felt] all of a sudden, an irresistible desire to return to the land of their birth. ${ }^{3}$ In this address, Crummell laid the foundation for the rhetoric that would define his colonizationist zeal.

Unlike many white advocates of black emigration, Crummell did not connect emigration to the ill treatment and lack of opportunities suffered by free blacks in the United States. Although it was after he carefully considered the lack of options for one such as himself in the racist North that Crummell chose to make his home in Liberia, he did not highlight this concern as central to his decision to forego a return to America. Crummell knew all too well that a black man was unlikely to realize his desire to assume the life of minister and scholar in America's high church. Returning to America with a distinguished degree only to be relegated once again to second class citizenship in both the government and the church was too humbling a prospect for Crummell. Despite his fear of the certain humiliation that awaited a would-be black intellectual like himself, he would not construct the image of Liberia as a refuge for downtrodden and dejected blacks from America. On the contrary, he carved an image of himself and fellow black emigrants as agents of providence coming to Liberia to lead native Africa to Christian redemption and civilization. His rhetoric of providence better fit his autonomous and authoritarian self-image. He found unacceptable the alternative image of one cast out to a pagan and uncivilized land. Crummell spent the better part of his life speaking out against slavery and racism; however, as his modern biographer, Wilson Moses, notes Crummell was "conservative, elitist and establishmentarian." ${ }^{4}$ Turning away from the dismal outlook of his future in America, Crummell arrived in Liberia in 1853 with his family, hopeful for a life as church leader and intellectual. 
Alexander Crummell's near twenty year stint in Liberia under the auspices of the Episcopal Church does not appear predicated on any early rooted convictions he held about the religious redemption of Africans nor about the eventual autonomy of African nations. In fact, as a minister and crusader for abolitionism and the rights of free blacks in the racist north of the 1830s and 1840s, Crummell spent his early activism calling for America to live up to its promise of liberty and equality. The young Crummell believed, as did many of his black contemporaries, that blacks should stay and fight for their rightful place and rewards in what was now their homeland, America. However, Crummell’s battles with the Episcopal Church opened his eyes to the alienation that black intellectual ambition invited, even among white church brethren in the North. While his degree from Queen’s College offered him a sense of vindication against those white church leaders in America who had refused him entry into the seminary, this triumph was short-lived. With degree in hand, Crummell's options were few. He, thus, turned his attention to Liberia, which he believed would prove the birthplace of an Anglo-African nation mirroring its parent nation, America, and led by educated and industrious blacks from America.

Liberia: The Wilderness and the New Light on the Hill

Crummell departed England for Liberia hoping that he was about to participate in the building of a black-Anglo nation on the African continent. He envisioned a black Liberia that would rival the Anglo-Saxon civilizations of England and America. British and American ties to Trans-Atlantic slavery and racial discrimination contradicted their claims of civility and greatness, but 
Crummell nevertheless, embraced their rhetorics of national superiority. While he often expressed a greater reverence for British culture, he made a significant borrowing from America's early patriarchs who espoused a providential rhetoric that validated their usurpation of native peoples and lands. Crummell envisioned a great AngloAfrican nation as the product of Liberian colonization, and he invoked the Puritan's rhetoric of providence to legitimate the means to that end. Providence, that term that was central to the early Puritan collective identity and later the concept that spurred American expansionism, found a central place in Crummell's nationalist vision. The Puritans' typological construct of themselves as divine agents of God's providential will would pave the way for centuries of unchecked white exploitation. They were God's pilgrims, the new Israelites --and America, the new Canaan. They were to build the new light on the hill and await the second coming of Christ. Incidental realities such as extermination of native people, confiscation of native homelands, and exploitation of black labor were the unpleasant fallout of divine destiny. Crummell appropriated this rhetoric of the conquerors, providing a prophetic note to his discourse that was at once nationalist and emigrationist. Crummell's reverence for the religion and culture of the white Atlantic informed his ambitions for Liberia, and he never seemed to acknowledge the irony of painting the black emigrants to Liberia in the likeness of America's Pilgrims. Crummell failed to recognize that the white Pilgrims who brought their Christianity and their civilization to America did so at a mortal cost to the native population. If he and other black emigrants fashioned themselves in the likeness of America's Pilgrims, their presence symbolized an ominous future for the very souls that he aimed to save on the African continent. 
Although his own father was a native African, Crummell found little in the culture of continental Africans that he imagined worthy of informing his vision of a black Anglo-African nation. He considered the economy, the education and the social conventions of the white world worthy of emulation. Failing to recognize the legitimacy and worth of the native people of Liberia, Crummell simply presumed that these were a people and a society in need of improvement. In Crummell's estimation, that improvement entailed an Anglo-informed makeover with a black emigrant leadership that would in his words, "organize the native labor ... introduce regulating and controlling law among them ... gather their children into schools, in order to train their intellects; to make these people civilized and Christian people. ${ }^{5}$

While on the one hand Crummell called on blacks from America to return to their homeland, on the other, he asked them to commit to a nationalist idealism that varied little from the cultural imperialism imposed by whites on African and American shores. Crummell blindly forged a rhetoric of Western superiority that, like his American models, called on native people to recognize their evident inferiority and thus submit to their cultural superiors. He summoned them to forsake their languages and their gods and maintained that by adopting the superior English language and converting to Christianity, Africans would build a nation worthy of comparison to the West. It is perhaps this contradictory and self-denigrating nature of his rhetoric that left Crummell a confirmed outsider, after nearly twenty years in Liberia. His nationalistic writings in Liberia represent the paradox of borrowing the conqueror's discourse to free oneself. Crummell armed himself with the very language and discourse that had sanctioned the enslavement of black Africans. He 
attempted to merge his black nationalist rhetoric with his deference for Westernrooted paradigms of civilization. The result, however, was a self-annihilating discourse that could imagine black progress only as a manifestation of Western Civilization. There was little African in Crummell's Africa, and in the end, his schismatic rhetoric left him disconnected from the very people he hoped to uplift.

Crummell and fellow black clergy such as the renowned theologian and emigrationist, Edward Blyden, offered numerous public communications on the success and divine purpose of the Liberian mission; however, the settling of Liberia was fraught with divisiveness among the emigrants themselves. AmericoLiberians were divided along color lines (mulatto and darker skinned blacks); they were also divided along class lines that were determined by an individual's pre-emigrant status as either free or slave, educated or illiterate, skilled worker or farm laborer. There was no monolithic cultural identity shared by the emigrant population, and oftentimes tensions between the emigrants proved more threatening to the mission than the strife between natives and settlers. ${ }^{6}$

Crummell failed to recognize the internal tensions that plagued the black settlers, and he was unable to see the stark difference between the American Pilgrims and the black emigrants to Liberia. In Crummell's mind the sign and the signified were universally transportable --the providential language of the American Pilgrims could be transported to signal the divineness of the emigrant mission in Liberia. America's Pilgrims traveled from England to the New World seeking the freedom to practice their own form of Christianity, free of persecution: they considered themselves God's divine people --Puritans --called upon like the biblical Israelites to fulfill a covenant between God and themselves. They deemed 
themselves the fulfillment or manifestation of Old Testament prophecy. In particular, they would bring to fruition the prophecy of the New Canaan that God promised the ancient Israelites. While they were not Jews or the descendants of Jews, their suffering at the hands of the then current religious persecutor --the English government and the Church of England --was no less divine. This typological exegesis, the reading of one's self or one's mission as a symbol and a presage of some biblical figure or event, predated the Puritan experience in America but set cultural roots there. As these self-proclaimed inheritors of the New Jerusalem successfully settled New England, their rhetoric came to define the mission of peopling America. ${ }^{7}$ They determined that they were the chosen people, and while some, such as William Bradford, would proclaim that spreading the word of the Gospel was among their purposes in removing to the New World, their establishment of a church in America was not precipitated by a call to convert and welcome native people into their religious fold. ${ }^{8}$ Theirs was a mission independent of native cooperation, and with a steady influx of settlers pushing into the interior, the Puritan vision of their New Jerusalem was safe from the threat of annihilation at the hands of native people.

Contrastingly, Crummell's new Jerusalem required the conversion of Liberia's native people --a conversion that he expected simply through their acceptance of Western Civilization as superior. Crummell's nationalist rhetoric echoed the histories recorded by Pilgrim fathers such as Increase Mather, Cotton Mather, John Winthrop, and William Bradford, who deemed the founding of America a fulfillment of biblical prophesy. However, without the imperialist tools of commerce and military might, Crummell's mere supposition that Western 
Civilization should be the model for a new Africa was not enough to move native Liberians. In his interpretation of Christianity in America, Crummell failed to recognize the central role that physical might and economic exploitation had played in the transformation of America into a Christian land. He was armed simply with his rhetoric and the scant funds he could solicit from the church and other sympathizers --not sufficient resources for nation building.

\section{Rhetoric and Logistics}

Crummell couched his colonialism in a providential rhetoric that maintained God as the master orchestrator; however, he was pragmatic in his vision of transforming the Liberian wilderness. He campaigned mightily, seeking both monies and bodies for the Liberia he envisioned, but as evident by today’s population count of five percent AmericoLiberians, he and fellow colonizationists were unable to influence significant numbers of blacks to emigrate to Liberia. Crummell was not unaware of the inherent problem of a low emigrant population. Several years after his arrival to Liberia, he expressed his concern over this problem. With no mincing of words, Crummell succinctly explained, "We need immigration. We are poor in men and women. We do not number over 14,000 emigrant citizens.” ${ }^{\prime 9}$ This shortfall in emigrant numbers jeopardized the growth that he considered key to a longstanding Liberian nation --one whose design was to be cast in the mold of America.

Borrowing from one of America’s expansionist visionaries, Crummell outlined the physical dimensions of the Liberia he envisioned: "We need this day for the great work before us, in a region of not less than 500,000 square miles, we 
need, I say, not less than 50,000 civilized men. We ought to be traveling onward through the land, and to appropriate and modify a remark of De Toqueville's, to be 'peopling our vast wilderness at the average rate of at least five miles per annum. ${ }^{\prime 10}$ Like De Toqueville, Crummell seemed indifferent to the population of natives that lived in the "vast wilderness" that he hoped to occupy.

Like the white settlers who invaded American shores, the black emigrants to Liberia found themselves in conflict with the native inhabitants. Emigrant settlements were established by the removal of native people: settlers acquired property rights and indigenous people were removed through legal agreements and war. Not unlike his American counterparts, Crummell overlooked the less than conciliatory relationship between settlers and native inhabitants, concerning himself primarily with what he deemed the great end of the mission. Crummell differed little from the first Liberian emigrants, who, arriving in 1820 under the auspices of the American Colonization Society, presumed that their prosperity in their New Canaan was imminent. Almost immediately, however, the first settlers were met by native Africans who engaged them in war over the land they hoped to claim. ${ }^{11}$ By the time Crummell arrived in 1853, black settlers and native Africans were locked in conflict, and Crummell would never witness the growth in the settler population that he had envisioned.

Crummell's understanding of the emigrants' severe numbers disadvantage probably heightened his promotion of English culture in Africa. The emigrants would not realize the needed numbers to forcibly occupy significant tracts of land or to confidently rule; therefore, native Liberians had to be persuaded that they should submit to a superior way of thinking and doing, and emigrants had to be reminded 
that they had been called to this civilizing mission. While Crummell was no advocate of slavery, he was willing to consider that it had been a medium for the fulfillment of God's divine plan. He would not deny that the enslavement of Africans was a human atrocity, but he imagined that this horror would bring eventual enlightenment to Africa. He suggested that one of the most significant consequences of slavery was the introduction of the English language to Africans. In one of his many addresses commemorating Liberia's independence, we find Crummell making the case for this belief. He instructs his fellow AmericoLiberians that their acquisition of English was tied to their providential mission in Liberia: Two years ago to-day [1858], when we were assembled . . . to celebrate our National Anniversary, I was called up ... to make a few remarks. And perhaps some, who are here, may remember that, in setting forth a few of the advantages we pilgrims to these shores possess, for a noble national growth and for future superiority; I pointed out among other providential events the fact, that the exile of our fathers from their African homes to America [italics mine], had given us, their children, at least this one item of compensation, namely, the possession of the Anglo-Saxon tongue ... ${ }^{12}$

The languages of Africans signaled their inferiority, and thus, by Crummell's argument were unfit instruments for civilization: "Because Africans languages are marked by 'the absence of clear ideas of Justice, Law, Human Rights, and Governmental Order' they are an inadequate medium to move African people to a civilized state."13 
Crummell argued that the English language provided blacks an important tool with which to pave Africa’s way to civilization. Civilizing Africa was not simply an arbitrary worldly quest: in Crummell's worldview, civilizing Africa was a providential edict, and the first Liberian emigrants represented the beginning of this special mission. He described their goal as a "most certain mission of enlightenment and elevation," and proclaimed that AmericoLiberians were "planted in this spot, on these shores [for] the promotion of grand civilization and human blessedness.” ${ }^{4}$ Crummell predicated his vision of African uplift on the presumption of Africa's inferiority.

Echoing Anglocentric negations of Africa and her people as possessing no signs of civilization, he speaks of Africa as the most wretched example of humanity:

Thrown thus back upon herself, unvisited by either the mission of letters, or of grace, poor Africa, all the ages through, has been generating, and then reproducing, the whole brood and progeny of superstitions, idolatries, and paganisms, through all her quarters. And hence the most pitiful, the most abject of all human conditions! And hence the most sorrowful of all histories! The most miserable, even now, of all spectacles! ${ }^{15}$

Crummell found Africa (Western Africa) absent of history and significant achievements, but not without hope. He argued that many a contemporary great nation arrived to prominence out of a barbarous and pagan past, and Africa was destined for a similar rise. Through the influence of civilizing elements, Africa would be lifted, and "educated free colored men” would prove the primary agents of 
this event. ${ }^{16}$ Crummell's elitist representations of national leadership reveal both his denigrating perceptions of native Africans, and also the beginnings of an elitist philosophy that he transformed into his "talented tenth" notion of leadership in postReconstruction America. Like the Anglo Puritans he emulated, Crummell constructed a rhetoric of colonization that represented God's divine will and coincidentally confirmed the emigrants as the earthly arbiters of this holy transformation.

According to Crummell, the end to Africa's benightedness was at hand: he argued that Africa would prove the fulfillment of the prophecy in Isaiah 60.3: "The Gentiles shall come to thy light, and kings to the brightness of thy rising.” In a footnote Crummell explained that the evidence of Africa's impending salvation was manifested in what he deemed the natives’ widespread desire for the Gospel. He claimed that the natives’ yearning for a "higher religion" was so strong that more missionaries were needed: "[t]he missionaries on the Gambia find themselves utterly unable to meet the earnest solicitations of the Foulahs, the Jalofs, and other tribes in Senegambia.... The call is so earnest at Lagos, at Abbeokuta, and in the interior from the banks of the Niger.... At Calabar, and at the Gaboon, the missionaries have been obliged to refuse the earnest request of the natives for more teachers and ministers. ${ }^{\text {17 }}$ Crummell's picture of natives yearning for the enlightenment of Westerners is reminiscent of similar images recorded by European explorers to new worlds. Christopher Columbus was among many who maintained a journal that painted the picture of a new land inhabited by peaceful, submissive natives --a land that investors might find worthy of exploration and settlement. Similarly, Crummell painted a picture of Africa that he hoped would inspire 
immigration and investment. Reminiscent of Columbus, Crummell anticipated an audience that would consider the risk of hostile engagements between emigrants and natives less likely if natives were eager converts.

The readiness of native Africans for Christian enlightenment fits with what Crummell deemed the imminent colonization of Liberia and the role of emigrants in that divine plan. Colonization had not occurred by the simple manipulation of men, but rather had been a providential tool employed by God throughout human history. Crummell called on the Old Testament story of the Hebrews' plight in Egypt to make this case. He explained the resettlement of the Hebrews in Canaan as divine colonization: "[s]ee the way in which God brought them into Egypt. Note their four centuries of servitude there; and then, at length, their triumphal exodus under Moses." ${ }^{18}$ Such was the history of African immigration; after suffering centuries of exile from their native Africa, Africans were to return to their ancestral homeland to bring Christianity and civilization. This colonization also answered the missionary call of the Gospels: citing Matthew 28:19, Crummell proclaimed that the emigrants were answering Jesus's charge to his disciples to go out among nations, baptizing and teaching in the name of the Trinity. ${ }^{19}$ Africa's great age was at hand, and this emerging civilization required that the pre-Christian practices and beliefs of the natives be eradicated. Presuming that the act and the actor were separate entities, Crummell supposed that this negation of native culture did not presume a negation of natives themselves. He argued that the civilized world recognized the bravery and virtue of native Africans; it was, therefore, not a matter of the character of the native, but rather the matter of his heathenish ways. The natives' "heterogeneous idolatries" had caused the "gross darkness" that prevailed over Africa, and "by the 
ordeal of Sassywood, Fetiches, human sacrifices, and devil-worship, [was] devouring men, women, and little children.”20

Informed by his Anglocentric worldview, Crummell showed no deference to the spiritual beliefs and practices of native Africans. He found nothing worthy of praise in the culture of native Africans; therefore, without trepidation, he offered up Africa to Christendom. With indifference to the native population, he emphasized the need for colonial expansionism. In the event that native Africans proved resistant to the leadership of black emigrants, the emigrants should then follow the policies of their Anglo-American models who, "by a policy, alike skillful and Christian ... quenched the ferocity of their Indian neighbours, and pushed their trade into the interior safe and unmolested., ${ }^{21}$ Delivered in a speech only two years before civil unrest would lead to the overthrow of the then AmericoLiberian led government, these words illustrate, again, Crummell's inability to distinguish the significant difference in circumstances between early Anglo-American settlers and the black emigrants to Liberia. Despite the rising dissention between natives and emigrants and the evident disadvantage in numbers for the emigrants, Crummell maintained a hegemonic rhetoric that painted the picture of a dominant emigrant presence.

The title of this 1870 speech, "Our National Mistakes and the Remedy for Them,” indicates Crummell's awareness that the colonizing mission was failing. In fact, Crummell's focus here was the failure of the emigrants in their dealings with the native population. But Crummell again demonstrated the persistence of his imperialist vision as his concern for the natives was rooted in the presumption of their innate inferiority. He explained that the tensions between natives and 
emigrants were embedded in the abrupt shift in the position of the emigrants, who “were metamorphosed from the position of underlings to one of mastery." 22 After living among native Africans for more than a decade, Crummell still held that they were a degraded people. Rather than consider that the tensions between natives and emigrants originated in the natives’ desire and capacity for self rule, Crummell imagined instead that the conflict had grown out of the emigrants’ mishandling of their native wards. According to Crummell, the stark contrast between the emigrants and their inferior kin led the emigrants to exaggerated notions of themselves, and even worse, the gulf between emigrant and native has led the emigrants to forget their duty to this population.

Crummell called on his fellow Liberians, that is, the emigrants, to change their treatment and perception of the natives. Reminiscent of white planters who spoke of the loyalty of their slaves, Crummell reminded the emigrants how faithfully the natives had served them and how they were thus worthy of their trust: "Have faith in the native. You have trusted him --trusted him to nurse your children --trusted him with your goods in trading --trusted your life in his hands, in fragile canoes --trusted yourself, unprotected, in his sequestered native villages. Go now to a farther length --trust him as a man.”23 This challenge to the black settlers to find peace with their native kin and to recognize their humanity was almost immediately undermined by Crummell's subsequent warning that when natives refused emigrant leadership, those in power might have to respond with force. To those who would argue that the emigrants had no right to force their laws and regulations on the natives, Crummell offered a justification that was rooted in his presumption of emigrant authority. He supposed that the position and circumstances of the settlers 
rendered them "the guardians, the protectors, and the teachers of [the] heathen tribes." ${ }^{24}$ The particular position and circumstance to which Crummell alluded was the divinely sanctioned mission of the settlers. Because they had been called upon by God to serve as special agents for the redemption of Africa and its people, the emigrants were thereby acting out of God's ultimate will. ${ }^{25}$

Crummell's presumption of divine agency allowed him to extend his Christian rhetoric to more secular nationalist concerns. He envisioned Liberia as a nation guided by Christian principles; thus, he found no conflict between his religious duty and his efforts to shape Liberia's government and economy. He was often criticized by church superiors for this seeming conflict of interest, but as Crummell revealed in his 1854 sermon, "God and Nation," he held firm to his conviction that his involvement in politics was consistent with his Christian duty: "my belief is that Christianity should permeate all the relations, and all the institutions of society; and hence that there is no true, faithful, exercise of the Christian ministry, unless that ministry causes the faith to touch everywhere with an illuminating, life-giving energy." ${ }^{26}$ Having thus affirmed the appropriateness of his secular crusades, Crummell plunged himself into national affairs. He was particularly interested in Liberia's economy, arguing that commerce was a natural outgrowth of religious enlightenment. He argued that "[t]here are few secular agencies so life-giving, so humane, and so civilizing, as is commerce. Let a nation sleep the sleep of a century's dullness, and then some propitious providence draw towards it the needs and desires of the nations; and up it starts to life and vigor."27

Crummell spoke passionately and frequently on commerce in Liberia, often detailing for would-be emigrants and supporters the particulars of Liberia's 
economy. For nearly two decades Crummell represented Liberia as a rising economic presence in Africa, often citing their cotton, coffee and palm oil production and growth in farming as evidence. He challenged anti-colonizationists, touting the potential for black wealth in Liberia as clear confirmation of the overall benefit of emigration. He suggested to his black skeptics that Africa was the providential inheritance of blacks, and its wealth was there waiting for blacks to seize what God has provided them. Crummell could not imagine that even his most confirmed skeptics would reject such a legacy: "How great so ever the diversities of opinion upon these points, on this platform, Douglass and Delany can stand beside the foremost citizens and merchants of Liberia. Hence those men whose feelings are the most averse to any thing like colonization, cannot object to the promotion of trade and the acquisition of wealth.,28

From his early to his final years in Liberia, Crummell maintained a providential rhetoric that tied the mission of African redemption to the rise of black wealth. As early as 1855, Crummell conveyed his concerns to fellow Liberians that the wealth of Africa might be enjoyed by those other than Africans. ${ }^{29}$ While Crummell envisioned an economically prosperous Africa, he did not imagine that African wealth should be controlled by native Africans. Again, black Americans were to be the agents of God's divine plan for Africa's economic prosperity: under this supposition Crummell campaigned tirelessly for black emigration to Liberia. He maintained that the emigrants were charged with establishing laws, schools and religious institutions that would civilize the natives. Crummell maintained a distance between natives and emigrants, with natives as outsiders to the Republic and emigrants as citizens. While native Liberians occupied most of the land in 
Liberia, Crummell did not recognize their right to land, nor did he acknowledge them as fit to have governmental or economic power. Like white settlers in early America, who under the guise of their proclaimed providential mission refused to recognize the Native Americans’ rights to property and wealth, Crummell subordinated native people and their interests. Crummell's design for a great Liberia called for a nation of workers subordinate to the authority of a small emigrant ruling class --an image that is strikingly similar to America's plantation South. He offered a perplexing vision of a once enslaved and exploited people returning to their ancestral homeland, but not as welcomed kin. The Liberian settlers were to lord over the natives much like the white settlers in America had assumed both ownership and authority of Native American lands and people.

The Fading Light

Given Crummell’s cursory acknowledgment of the concomitant extermination of indigenous people and the brutal exploitation of African people in the providential making of America, his indifference to native Africans was not altogether remarkable. Crummell sought a nation for blacks like himself to bring to fruition their elitist desires, and this included the desire for material gain. In an 1870 address to fellow Liberians he revealed this most poignantly as he exclaimed, "a common complaint throughout the length and breadth of the land ... [is] the slowness of our accumulation of wealth!”30 These words, however, delivered within two years of Crummell's departure from Liberia, hint at the elusiveness of his vision. 
Having spent nearly twenty years in Liberia, with no wealth of his own and no signs of the AngloAfrican empire he had anticipated, Crummell recommended that "nothing but a complete, but healthful, revolution of plans and policies, can give this nation success and aggrandizement." ${ }^{31}$ While he still asserted the providential authority of the emigrants to govern and guide Liberia's emergence, his call for a "revolution of plans and policies" reveals the failure of his AmericoLiberian vision. Ironically, Liberia experienced a major change in 1870, but not the revolution Crummell anticipated. In the aftermath of the 1870 election, the dominance of the mulatto political faction was threatened, and Liberia was thrown into civil unrest. This political turmoil precipitated the end of Crummell's Liberian mission. In 1872 he departed, leaving a predominant native population that still held to its traditional religions, languages and cultural practices,

In part, Crummell's failed discourse resulted from his own blind desire; however, if we turn to the title of Audre Lorde’s frequently cited essay, "The Master's Tools Will Never Dismantle the Master’s House,” we can understand Crummell's failure more critically as a miscalculation of the transportability of discourse. ${ }^{32}$ Can the master's discourse be used to overthrow the master and liberate one's self? Crummell's providential rhetoric suggests not. Crummell could not seamlessly transform America's rhetoric of divine providence into a rhetoric of black nationalism. America’s Puritans had a divine mission --they were bringing to fruition the promise of a New Canaan. To fulfill their providential calling, however, they had to free themselves from the religious tyranny of an earthly enemy --the Church of England. Like the Puritans, Crummell claimed that his was a divinely ordained mission: he did not, however, tie his providential rhetoric to the liberation 
of emigrants or native Liberians from their earthly enemy --white enslavers and colonizers. Crummell's spiritual rhetoric of providential deliverance was weakened by its absence of a worldly struggle and a material adversary. Native Liberians faced Western invaders who usurped their people and their natural resources. Crummell did not imagine that their struggle for deliverance in this world should be merged into a rhetoric of dual deliverance. Trapped by his own discourse, Crummell could no more lead native Liberians to deliverance than he could himself.

In his nationalist rhetoric, Crummell failed to fully explore the destructive consequences suffered by native people with the coming of Westerners and Christianity. Instead, he offered an Anglocentric history of the spread of Christianity, suggesting that "[u]nder the influence of Christianity, the idea of brotherhood has been gaining influence and authority; so, likewise, the principle of national good-will has kept pace with the moral progress of the age. Ruthless brute force, unreasoning domination, no longer decide the fate of inferior nations.”33 Crummell seemed unaware of the "brute force" and "unreasoning domination" that by the middle of the nineteenth century had become standard practice in European conquests across the globe. Europeans were bringing Christianity to lands and people in the most remote of places; however, they did not bring their religion with offerings of brotherhood to the indigenous people they met. In the Americas, in Africa, and in Asia, Europeans were seeking to expand their empires and their wealth, and in most cases, native inhabitants paid severely in loss of life, land and culture. Crummell's ahistorical reading of AngloChristianity and colonialism provided a missionary discourse for his Liberian campaign, but at a cost that Crummell was unable to fully recognize. He acknowledged that "[n]o people lose 
entirely their native tongue without the bitter trial of hopeless struggles, bloody strife, heart-breaking despair, agony, and death!” He explained, however, that "this fact of humiliation seems to have been one of those ordinances of providence, designed as a means for the introduction of new ideas into the language of a people; or to serve, as the transitional step from low degradation to a higher and nobler civilization.”34 Crummell's reduction of "bloody strife,” “despair,” and “death” to mere "humiliation" exemplifies his propensity to disregard the severe sufferings of those who were being civilized. Most importantly, in his hegemonic vision, he failed to consider that in the eyes of native Africans the promise of Christian redemption and Western Civilization might not be a sufficient reward for their loss and suffering.

Crummell's failed rhetoric highlights native Liberians' resistance to a Western hegemonic discourse that intrinsically threatened their humanity and identity. To abandon their language for English and to accept this as a necessary step to divine grace and human progress would have amounted to self-erasure. They understood better than Crummell his assertion that "a language acts in divers ways, upon the spirit of a people.” ${ }^{35}$ It was perhaps their understanding that language has the power to negate or erase the human self that guided native Liberians to resist the adoption of English. Unlike Crummell, they were not inclined to forsake their language for the language of the invaders. Crummell's premise that language is a force that can both act on and be acted upon by people was not lost on native Liberians. They seemed to understand better than Crummell that those who are forcibly subjected to a language can and often do appropriate that language to resist its domination. 
Crummell promoted the appropriation of English, however, not as a form of resistance, but rather as a means of assimilation. The appropriation of English by Africans would represent their transformation into Anglo-Africans, who, after taking on the spirit of that language would leave their African sensibilities behind. Crummell was never able to influence a widespread adoption of English among native Liberians, and even as he promoted English, he seemed paradoxically aware that Africans who took up this language did so only on their own terms. He noted that in many instances natives who showed no other inclination for Western ways spoke English with clarity and distinction. ${ }^{36}$ Rather than understanding this as an example of a people acting upon a language --in this case, native Liberians defining and restricting English to a language of trade and external negotiation --he considered this an example of African heathenism unchecked.

To witness the fulfillment of his Liberian vision, Crummell required native Liberians to acknowledge their inferior status and to submit themselves to a makeover under the authority of their emigrant brethren. Native Liberians would not comply: their resistance rendered Crummell's rhetoric little more than words. While the AngloAmerican model of providence that informed Crummell's rhetoric was no more providential than Crummell's vision, it could be recorded as such because the American settlers won out over their native adversaries. History suggests that providence requires the accompanying hand of force. Low emigrant numbers and insufficient national wealth and might presaged the unlikely fruition of Crummell's providential vision; however, it was his ahistorical reading of Christianity and colonialism that sealed his failure. Crummell accepted readings of black Africa as a land marked by an inferior people and culture. He expected native Liberians to 
accept this Anglocentric gaze and to then cheerfully submit to make themselves over in the image of their white superiors.

Crummell had constructed himself into the likeness of the white Christian conquerors that he admired; perhaps this explains why he so enthusiastically expected native Liberians to follow suit. The exemplum of nineteenth-century Western intellectualism and religiosity, he was the scholar theologian, and he had reached this height through his deliberate acculturation of all he deemed great in Western society. The legacy of his father’s African identity was insignificant to Crummell's core construct of himself. He did not find that his Anglophilic worldview had cost him a meaningful link to his history and culture, and this view informed his inability to connect with the larger native Liberian population.

Crummell left a paradoxical legacy of self-love and self-loathing. Scholars have recognized him as one of the early fathers of black nationalism, but they have also noted his low estimation of black culture and history. It is this conflicting nature of Crummell's rhetoric that led to his obscurity at the dawn of the twentiethcentury African American Renaissance. Crummell had been a revered figure among the black intelligentsia of middle and late nineteenth-century America. However, as Africa became a symbol of a reclaimed ancestry in the works of many Harlem Renaissance writers, black artists and thinkers awarded less attention to black Anglophiles like Crummell. Today, scholarship on Crummell focuses primarily on his historical significance. While Crummell's activism provides significant insight into the political and cultural world of free blacks pre- and post-emancipation, his writings highlight the colonial roots of class tensions within black societies in Africa as well as America. Crummell's Liberian rhetoric especially demonstrates 
how Western presumptions on the authority of the written word contributed to these tensions. Blacks took to pen and paper in great part to combat slavery and discrimination; however, many blacks internalized the notion that the written word had authority and primacy over the spoken. Crummell extended this presumption further: he would employ the written word to suggest a reality that was little more than his own desire. His providential rhetoric outlined a world in which blacks would accept a promise of deliverance that ironically delivered them over to an elite ruling class. He offered the vision of a divinely inspired leadership and the unlettered and unenlightened masses left to its charge. Although native Liberians overwhelmingly rejected this social vision, Crummell continued to offer this representation of Liberia to his American and English audiences as well as to those who lived in Liberia. As one of Liberia's few black men of letters, Crummell was considered a voice of authority in the eyes of his Western audiences. This validation fueled Crummell's rhetoric and confirmed his reputation among his intellectual peers. However, among the greater population of native Liberians, his validation from Westerners served to solidify the gulf between Crummell and themselves. His rhetoric served the interests of the masters and, thus, offered no possibilities for deliverance from their exploitation.

Notes

${ }^{1}$ The full communication can be found in The (Rochester, New York) North Star, June 15, 1849.

${ }^{2}$ (Rochester, New York) Frederick Douglass’ Paper, 31 August 1855. 
${ }^{3}$ Alexander Crummell, "Hope for Africa," in The Future of Africa (1862; reprint, New York: Negro Universities Press, 1969), 295-96.

${ }^{4}$ Wilson Jeremiah Moses, Alexander Crummell: A Study of Civilization and Discontent (New York: Oxford University Press, 1989), 6-7.

${ }^{5}$ Alexander Crummell, "Emigration, an Aid to the Evangelization of Africa," in Africa and America (1891; reprint, Miami, FL: Mnemosyne Publishing, 1969), 422.

${ }^{6}$ James Fairhead, Tim Geysbeek, Svend E. Holsoe, and Melissa Leach, eds., Introduction to African-American Exploration in West Africa: Four NineteenthCentury Diaries (Bloomington: Indiana University Press, 2003), 18-23.

${ }^{7}$ For a more detailed account of biblical typology in early American discourse see Thomas M. Davis, “The Traditions of Puritan Typology,” in Typology and Early American Literature, ed. Sacvan Bercovitch (Amherst, University of Massachusetts Press, 1972). Additionally, Sacvan Bercovitch, Puritan Origins of the American Self (New Have: Yale University Press, 1975) is a landmark study of the Puritan influence in the discourse of American identity.

${ }^{8}$ See William Bradford, Of Plymouth Plantation (NY: Knopf, 1952) for Bradford's detailed account of the Puritans’ providential destiny.

${ }^{9}$ Alexander Crummell, "The Relations and Duties of Free Colored Men in America to Africa," in The Future of Africa, 254.

${ }^{10}$ Crummell, "The Relations and Duties of Free Colored Men in America to Africa,” 255.

${ }^{11}$ Charles Johnson, Bitter Canaan (New Brunswick: Transaction Books, 1987) explores the dynamics of this historical confrontation, capturing the Puritan-like 
discourse that gave the emigration mission a tone of divine purpose. We get a sense of the enduring threads of detestation and discontent woven first in the earliest clashes between emigrant and native Liberians in Johnson's study, as well as in works such as Diane Frost's Work and Community among West African Migrant Workers Since the Nineteenth Century (Liverpool: Liverpool University Press, 1999), Catherine Reef's This Our Dark Country: The American Settlers of Liberia (New York: Clarion Books, 2002), and Claude Clegg’s The Price of Liberty: African Americans and the Making of Liberia (Chapel Hill: University of Chapel Hill, 2004),

12 Alexander Crummell, “The English Language in Liberia,” in The Future of Africa, 9.

${ }^{13}$ Crummell, “The English Language in Liberia,” 20.

${ }^{14}$ Alexander Crummell, "The Responsibility of the First Fathers of a Country for Its Future Life and Character,” in Africa and America, 151.

${ }^{15}$ Alexander Crummell, “The Progress of Civilization Along the West Coast of Africa,” in The Future of Africa, 108.

${ }^{16}$ Crummell, “The Progress of Civilization along the West Coast of Africa,” 146.

${ }^{17}$ Alexander Crummell, “Hope for Africa,” 305.

${ }^{18}$ Alexander Crummell, "Emigration, an Aid to the Civilization of Africa," in Africa and America, 416.

${ }^{19}$ Alexander Crummell, “The Regeneration of Africa,” in Africa and America, 433. Crummell errs in citing the passage as verse 28; it is verse 19. 
${ }^{20}$ Alexander Crummell, “The Relations and Duty of Free Colored Men in America to Africa,” in The Future of Africa, 220.

${ }^{21}$ Alexander Crummell, “Our National Mistakes and the Remedy for Them,” in Africa and America, 189.

${ }^{22}$ Crummell, “Our National Mistakes,” 170.

${ }^{23}$ Crummell, “Our National Mistakes,” 183.

${ }^{24}$ Crummell, “Our National Mistakes,” 184.

${ }^{25}$ The parallel that Crummell draws between the emigrants and the biblical stories of Joseph and Moses resonate in this assertion. The stories of Joseph and Moses illustrate biblical emigration, and the two patriarchs highlight God's entrustment of his authority to human agents.

${ }^{26}$ Alexander Crummell, “God and Nation,” in The Future of Africa, 151.

${ }^{27}$ Alexander Crummell, “The Duty of a Rising Christian State,” in The Future of Africa, 71.

${ }^{28}$ Alexander Crummell, “The Relations and Duty of Free Colored Men in America to Africa," 245.

${ }^{29}$ Crummell, “The Duty of a Rising Christian State,” 89-90.

${ }^{30}$ Crummell, “Our National Mistakes,” 176.

${ }^{31}$ Crummell, “Our National Mistakes,” 169.

32 The full essay can be found in Audre Lorde, Sister Outsider (Trumansburg, NY:

Crossing Press, 1984).

33 Alexander Crummell, “The Duty of a Rising Christian State,” in The Future of Africa, 67. 
${ }^{34}$ Crummell. “The English Language in Liberia,” 18.

${ }^{35}$ Ibid., 52.

${ }^{36}$ Ibid., 14. 